\title{
Frequency Analysis as a Way of Uncovering News Foci: Evidence from the Guardian and the New York Times
}

\author{
Ahmad S. Haider ${ }^{1}$ \\ ${ }^{1}$ Department of Linguistics, University of Canterbury, New Zealand \\ Corresponding author: Ahmad S. Haider, Department of Linguistics, University of Canterbury, Private Bag 4800, \\ Christchurch 8140, New Zealand. E-mail: ah_haider86@yahoo.com
}

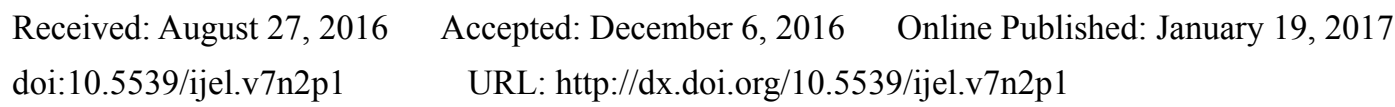

\begin{abstract}
Institutions or people can express their political stances or attitudes toward a specific topic if they keep using some words rather than others repetitively and consistently. This study uses the corpus linguistic technique of frequency to examine the influence of the country where the newspaper is published on its agenda and coverage using a corpus of about 7 million words of news articles about Libya and Qaddafi in the Guardian (Britain) and the New York Times (the U.S.) from 2009 to 2013. The compiled corpus is divided into three time periods, namely: before, during, and after the 2011 Arab uprisings. The analysis shows that the two newspapers had different news foci/themes in the three investigated time periods, and that they are influenced by the stock of ideas circulating in the culture in which they are working. Both newspapers covered more news of events that draw the attention of the people of the countries where they are located and published. The paper concludes that there is a strong relationship between media and politics where media is a central arena for viewing the political events.
\end{abstract}

Keywords: corpus linguistics, frequency analysis, the Guardian, the NYT

\section{Introduction}

Discourse, being "language in action" Blommaert (2005, p. 2), is effective and influential in society since it causes changes and constructs events and behaviours (Van Dijk, 1997). Burr (1995) states that discourse is a way of interpreting the world, giving it a meaning, and allowing some events rather than others to take place. Since discourse is constructed via language and corpus is a collection of naturally occurring language, it may be argued that corpora provide their users with some information about the societies in which that language is used. Language plays an important role in influencing and forming people's attitudes and ideologies, urging them to act in a specific way rather than another (Van Dijk, 2001). Therefore, language is not a discourse in itself, but a way that influences people to act in a particular way, which can be regarded as traces of a particular discourse. To link these aspects with corpus linguistics, Baker (2010) argues that a corpus contains a collection of naturally occurring language, and has repetitions and patterns that suggest discourse traces, and discourse can be made to be naturalized by being reiterated in everyday language.

This study uses the analytical framework of Corpus Linguistics (CL) in general, and the technique of frequency in particular to discursively examine the most frequent themes in the Guardian (Britain) and the New York Times (the U.S.) in a corpus of about 7 million words of news articles about Libya and Qaddafi. It also examines whether there are any constant/frequent discourses with Qaddafi in the two newspapers in a time span of 5 years from 2009 to 2013. It follows the research paradigm of Corpus-Assisted Discourse Studies (CADS) (Partington, Morley, \& Haarman, 2004) since it fits between the quantitative and qualitative poles, and attempts to combine the advantages of each to create more powerful analyses of linguistic data.

This paper contributes to the growing body of studies that use the methodological framework of Corpus Linguistics to uncover discourses. Since the outbreak of the Arab Spring in 2011, many scholars have conducted several studies about this era from different points of view-politically, economically, socially, and linguistically (see Abu Hatab, 2013; Al-Ali, 2012; Al-Anani, 2012; Jones, 2012; Michel, 2013; Springborg, 2011). Some of these studies discussed the mass media coverage of the Arab Spring (see Al Nahed, 2015; Bardici, 2012; Baum \& Zhukov, 2015; Cottle, 2011; Dağtaş, 2013; Ledwell, 2012; Seeberg \& Shteiwi, 2014; Seo, 2013). Other studies used some traditional discourse analysis frameworks to interpret some different aspects of this era (see Al-Abed, 
Al-Haq, \& Hussein, 2012; Maalej, 2012; Skulte-Ouaiss \& Baroudi, 2015; Teti, 2012). However, most of these studies used a relatively small amount of data, and paid little or no attention to the newspaper coverage of different regions. Therefore, one of the research gaps that this study fills is working on a large amount of data to examine the news foci of two English newspapers' coverage of events and news about the regime of Qaddafi. This study further contributes to having a better understanding of how the policies and ideologies of where a newspaper is located may affect how certain events are represented.

\section{Theoretical Background}

Corpus linguistics is "the study of language based on examples of "real life" language use" (McEnery \& Wilson, 2001, p. 1). Corpus linguistics has largely been accepted as an important way of analysing language in different fields such as lexicography (Hanks, 2012), syntax (Roland, Dick, \& Elman, 2007), discourse analysis (Baker, 2006), cognitive linguistics (Gries \& Stefanowitsch, 2007), and applied linguistics (Hunston, 2002). Hardt-Mautner (1995) investigates the computer's ability to uncover discourses, and recommends that qualitative and quantitative techniques need to be combined, not play off against each other. Similarly, McEnery \& Wilson (2001) argue that combining both quantitative and qualitative approaches offers two main advantages; namely it makes the qualitative analysis more precise, and the quantitative results more reliable and generalizable. Corpus linguistics has a variety of techniques, and it is the choice of researchers to select the most appropriate techniques that help them carry out their research properly.

Frequency analysis, which is quantitative in nature, can contribute to discourse analysis that normally follows a qualitative method of analysis. This study shows how the quantitative analysis which recognizes patterns of language is used to show whether the phenomenon is common or usual, and how numbers cannot tell everything about the language, and must be tied with qualitative analysis to provide functional interpretations of language patterns (Baker, 2006). Frequency analysis allows researchers to count how many times the element occurs in the corpus. It also enables researchers to recognize the most frequent words in a particular corpus, and then compare and contrast them with other frequent words in other corpora. Frequency can reveal some facts about discourse and attitudes, and can be an indicator of markedness which is a way to understand something based on its relation with other things, sometimes by its opposite (a binary distinction) (Baker, 2010). For example, examining the frequencies of words like natural and unnatural in the British National Corpus (BNC) revealed that people prefer the former over the latter; where natural was mentioned 14,068, while unnatural was mentioned only 463 (Baker, 2010). Analysing frequencies may also provide researchers with the focus of the corpus. For example, Haider (2016) employed a 19.5-million word corpus of newspaper articles, and used the corpus linguistic technique of frequency to examine the main discussed themes in Asharq Al-Awsat (a pan-Arab newspaper) and Al-Khaleej (a UAE national newspaper) in a time span of 5 years. The findings showed that the two newspapers had different themes based on their agendas and policies; however, at the times of war and conflict, they tend to have a similar focus. Examining the most frequent words in their context may suggest some other aspects to be studied closely, such as the authors' political stance, and the reasons that motivated them to select particular words and repeat them over their texts (Baker, 2006). Institutions or people can express their political stances or attitudes toward a specific topic if they keep using some words rather than others repetitively and consistently, given the fact that the meaning of words is dynamic and can be changed or expanded (Breheny, 2003). Frequency is important for discourse analysis because language is not a random affair, and people have the choice to select which words to use and which words to neglect or not use. Their choices, therefore, may reveal something about the ideology, attitudes and intention of text producers.

\section{Corpus Collection}

The two selected newspapers in this study are The NYT and The Guardian. What distinguishes them from their rivals is their high coverage of international issues. For example, Kautsky \& Widholm (2008) mentions that 78\% of the Guardian's online readers are from outside Britain. In the same vein, the NYT is a "leading newspaper with regard to the coverage of international news and views, drawing readers from every state and around the world" (Izadi \& Saghaye-Biria, 2007, p. 148).

According to industry analyst ComScore (ComScore Data Mine, 2012), Mail Online, New York Times and The Guardian ranked first, second, and third respectively as the most read online newspapers. The Guardian has passed the NYT in 2014, and became the world's second most popular English-language newspaper website, according to comScore (The Guardian, 2014). Mail Online which is the website of the Daily Mail was excluded because it is a tabloid newspaper not a broadsheet. This research is limited to broadsheet newspapers because tabloids sensationalise news using images and headlines to dominate the page (Sparks, 2000; Uribe \& Gunter, 2004). In addition, this study depends on a huge amount of data and a large body of text, and broadsheets tend 
to have longer and more detailed articles than tabloid (Douglas, 2009).

The corpus used in this study is originally built to investigate the representation of the former Libyan regime of Qaddafi before and after the 2011 Libyan uprisings. Libya is selected as a focus of this study because its leader, Qaddafi, ruled the country for almost four decades that resulted in UN sanctions and Libya's status as a pariah state. Libya is different because it is one of the wealthiest countries in the world, but still its internal situation is poor. Libya and Qaddafi are indeterminate objects in both Arab and global ideologies; Qaddafi is a self-produced object, and the country is both ideal and anomalous in Arab discourse, and this makes them fruitful topics for further investigation.

The query terms chosen to compile the corpus are Libya*, Qaddafi, and some Libyan cities, namely Benghazi, Tripoli, and Sirt. The compiled articles were then divided into three periods, namely: before, during, and after the uprisings. Period 1 (before the uprisings) spans from January 2009 to December 2010. Period 2 (during the uprisings and the immediate aftermath of the event) is from January 2011 to December 2011. Period 3 (after the uprisings) covers events from January 2012 to December 2013. Looking for the query terms in Factiva between $(1 / 1 / 2009)$ and (31/12/2013) in The NYT and The Guardian resulted in 8793 articles with a total word count of 7345100 (Table 1).

Table 1. The size of the compiled corpus

\begin{tabular}{|c|c|c|c|c|c|c|}
\hline \multicolumn{7}{|c|}{ The NYT } \\
\hline Period & Year & Number of Articles & Duplicates & Total & Word count & Total of periods \\
\hline \multirow{2}{*}{ Before } & 2009 & 350 & 92 & 258 & 202425 & \multirow{2}{*}{357445} \\
\hline & 2010 & 203 & 37 & 166 & 155020 & \\
\hline During & 2011 & 2825 & 500 & 2325 & 2174932 & 2174932 \\
\hline \multirow{2}{*}{ After } & 2012 & 1434 & 358 & 1076 & 1085866 & \multirow{2}{*}{1921381} \\
\hline & 2013 & 1123 & 333 & 790 & 835515 & \\
\hline Total & 5 years & 5935 & 1320 & 4615 & 4453758 & 4453758 \\
\hline \multicolumn{7}{|c|}{ The Guardian } \\
\hline \multirow{2}{*}{ Before } & 2009 & 535 & 206 & 329 & 210626 & \multirow{2}{*}{400482} \\
\hline & 2010 & 386 & 119 & 267 & 189856 & \\
\hline During & 2011 & 3371 & 964 & 2407 & 1596768 & 1596768 \\
\hline \multirow{2}{*}{ After } & 2012 & 1105 & 387 & 718 & 536403 & \multirow{2}{*}{894092} \\
\hline & 2013 & 722 & 265 & 457 & 357689 & \\
\hline Total & 5 years & 6119 & 1941 & 4178 & 2891342 & 2891342 \\
\hline Overall Total & 5 years & 12054 & 3261 & 8793 & 7345100 & 7345100 \\
\hline
\end{tabular}

\section{Data Analysis}

This study has two research questions:

- $\quad$ Are there any constant/frequent discourses with Qaddafi in The Guardian and The NYT from 2009 to 2013 ?

- What are the most frequent topics/themes discussed in news articles relating to Libya and Qaddafi in The Guardian and The NYT in the pre-, during, and post- uprisings periods?

Using the wordlist tool of the corpus analysis software Word Smith 6 (Scott, 2012), I generated frequency lists for the three time periods in the two investigated newspapers. In the process, the most frequent lexical 25 words were considered as shown in tables 2 (the Guardian) and 3 (the NYT). 
Table 2. The top 25 lexical words in the Guardian

\begin{tabular}{|c|c|c|c|c|c|c|c|c|}
\hline \multicolumn{9}{|c|}{ The Guardian } \\
\hline \multicolumn{3}{|c|}{$2009 / 2010$} & \multicolumn{3}{|c|}{2011} & \multicolumn{3}{|c|}{$2012 / 2013$} \\
\hline Word & R. Freq. & N. Freq. & Word & Freq. & N. Freq & Word & Freq. & N. Freq \\
\hline SAID & 1,430 & 3,571 & QADDAFI & 6,953 & 4,354 & SAID & 3,744 & 4187.489 \\
\hline MEGRAHI & 955 & 2,385 & SAID & 6,888 & 4,314 & LIBYA & 1,937 & 2166.444 \\
\hline LIBYA & 932 & 2,327 & LIBYA & 5,731 & 3,589 & SYRIA & 1,752 & 1959.53 \\
\hline GOVERNMENT & 767 & 1,915 & PEOPLE & 3,704 & 2,320 & PEOPLE & 1,639 & 1833.145 \\
\hline WORLD & 630 & 1,573 & LIBYAN & 2,910 & 1,822 & GOVERNMENT & 1,585 & 1772.748 \\
\hline PEOPLE & 629 & 1,571 & GOVERNMENT & 2,761 & 1,729 & NEW & 1,264 & 1413.725 \\
\hline BRITISH & 585 & 1,461 & REGIME & 2,331 & 1,460 & WAR & 1,255 & 1403.659 \\
\hline NEW & 583 & 1,456 & FORCES & 2,284 & 1,430 & WORLD & 1,181 & 1320.893 \\
\hline LIBYAN & 575 & 1,436 & MILITARY & 2,274 & 1,424 & MILITARY & 1,165 & 1302.998 \\
\hline QADDAFI & 565 & 1,411 & NEW & 2,176 & 1,363 & SECURITY & 1,138 & 1272.8 \\
\hline RELEASE & 530 & 1,323 & TRIPOLI & 2,105 & 1,318 & SYRIAN & 1,044 & 1167.665 \\
\hline YEARS & 529 & 1,321 & WORLD & 2,079 & 1,302 & QADDAFI & 1,024 & 1145.296 \\
\hline SCOTTISH & 499 & 1,246 & WAR & 2,017 & 1,263 & REGIME & 1,019 & 1139.704 \\
\hline TIME & 497 & 1,241 & COUNTRY & 1,982 & 1,241 & TIME & 1,009 & 1128.519 \\
\hline UK & 465 & 1,161 & NATO & 1,918 & 1,201 & COUNTRY & 995 & 1112.861 \\
\hline BRITAIN & 410 & 1,024 & ARAB & 1,780 & 1,115 & YEARS & 992 & 1109.506 \\
\hline INTERNATIONAL & 384 & 959 & TIME & 1,741 & 1,090 & YEAR & 947 & 1059.175 \\
\hline FOREIGN & 382 & 954 & FOREIGN & 1,737 & 1,088 & FOREIGN & 946 & 1058.057 \\
\hline MINISTER & 377 & 941 & BRITISH & 1,693 & 1,060 & BRITISH & 937 & 1047.991 \\
\hline WAR & 364 & 909 & LIKE & 1,664 & 1,042 & INTERNATIONAL & 917 & 1025.622 \\
\hline DECISION & 353 & 881 & UK & 1,648 & 1,032 & OBAMA & 903 & 1009.963 \\
\hline COUNTRY & 352 & 879 & REBELS & 1,611 & 1,009 & PRESIDENT & 894 & 999.8971 \\
\hline LIKE & 349 & 871 & BRITAIN & 1,580 & 989 & ARAB & 830 & 928.3161 \\
\hline POUNDS & 341 & 851 & YESTERDAY & 1,565 & 980 & ASSAD & 820 & 917.1316 \\
\hline LOCKERBIE & 340 & 849 & YEARS & 1,535 & 961 & LIKE & 806 & 901.4732 \\
\hline
\end{tabular}

Table 3. The top 25 lexical words in the NYT

\begin{tabular}{|c|c|c|c|c|c|c|c|c|}
\hline \multicolumn{9}{|c|}{ The NYT } \\
\hline \multicolumn{3}{|c|}{$2009 / 2010$} & \multicolumn{3}{|c|}{2011} & \multicolumn{3}{|c|}{$2012 / 2013$} \\
\hline Word & R. Freq. & N. Freq. & Word & R. Freq. & N. Freq. & Word & R. Freq. & N. Freq. \\
\hline SAID & 2,371 & 6,633 & SAID & 17,051 & 7,840 & MR & 14,272 & 7427.990596 \\
\hline MR & 1,981 & 5,542 & MR & 10,989 & 5,053 & SAID & 13,396 & 6972.068528 \\
\hline NEW & 909 & 2,543 & LIBYA & 7,719 & 3,549 & OBAMA & 4,835 & 2516.41918 \\
\hline UNITED & 862 & 2,412 & QADDAFI & 6,681 & 3,072 & PRESIDENT & 4,375 & 2277.008048 \\
\hline LIBYA & 825 & 2,308 & GOVERNMENT & 5,660 & 2,602 & GOVERNMENT & 4,193 & 2182.284513 \\
\hline GOVERNMENT & 746 & 2,087 & PEOPLE & 4,518 & 2,077 & SYRIA & 4,091 & 2129.197697 \\
\hline STATES & 684 & 1,914 & UNITED & 4,360 & 2,005 & UNITED & 4,039 & 2102.13383 \\
\hline PRESIDENT & 541 & 1,514 & NEW & 4,148 & 1,907 & LIBYA & 3,634 & 1891.347942 \\
\hline AMERICAN & 538 & 1,505 & COLONEL & 3,910 & 1,798 & NEW & 3,449 & 1795.06303 \\
\hline PEOPLE & 525 & 1,469 & LIBYAN & 3,892 & 1,789 & STATES & 3,335 & 1735.730706 \\
\hline NUCLEAR & 515 & 1,441 & MILITARY & 3,824 & 1,758 & PEOPLE & 3,151 & 1639.966253 \\
\hline WORLD & 510 & 1,427 & PRESIDENT & 3,701 & 1,702 & SECURITY & 3,107 & 1617.066058 \\
\hline LIKE & 508 & 1,421 & STATES & 3,407 & 1,566 & MILITARY & 3,001 & 1561.897406 \\
\hline YEARS & 499 & 1,396 & FORCES & 3,400 & 1,563 & AMERICAN & 2,980 & 1550.967767 \\
\hline OFFICIALS & 471 & 1,318 & REBELS & 3,205 & 1,474 & LIKE & 2,522 & 1312.597554 \\
\hline OIL & 450 & 1,259 & OBAMA & 3,160 & 1,453 & STATE & 2,446 & 1273.042671 \\
\hline LIBYAN & 422 & 1,181 & COUNTRY & 3,143 & 1,445 & OFFICIALS & 2,436 & 1267.838081 \\
\hline Megrahi & 415 & 1,161 & LIKE & 2,840 & 1,306 & WORLD & 2,306 & 1200.178413 \\
\hline OBAMA & 406 & 1,136 & WORLD & 2,724 & 1,252 & COUNTRY & 2,303 & 1198.617036 \\
\hline COUNTRY & 405 & 1,133 & OIL & 2,704 & 1,243 & WAR & 2,264 & 1178.319136 \\
\hline ISRAEL & 399 & 1,116 & NATO & 2,673 & 1,229 & POLITICAL & 2,262 & 1177.278218 \\
\hline INTERNATIONAL & 391 & 1,094 & OFFICIALS & 2,524 & 1,160 & SYRIAN & 2,262 & 1177.278218 \\
\hline STATE & 388 & 1,085 & SECURITY & 2,522 & 1,160 & ATTACK & 2,220 & 1155.418941 \\
\hline COUNTRIES & 386 & 1,080 & ARAB & 2,506 & 1,152 & TIME & 2,176 & 1132.518746 \\
\hline IRAN & 373 & 1,044 & TRIPOLI & 2,419 & 1,112 & FOREIGN & 1,944 & 1011.772262 \\
\hline
\end{tabular}


Tables 2 and 3 show the most frequent words in the two newspapers based on the investigated period. The three columns in each period include information about the word, its raw frequency (how many times it occurs in the corpus), and its normalized frequency (its occurrences per million words). The words that appear in the three time periods are bolded in these tables.

Section 4.1 examines the words that occurred in the three time periods to check if Qaddafi was represented similarly/differently across the three time periods. Section 4.2 investigates the words that occurred uniquely in (a) particular period(s) rather than others to uncover the different news foci in the two newspapers in the three periods.

\subsection{The Similarities in the Frequent Lexical Words in the Three Periods}

Some words, bolded in tables ( 2 and 3 ), occurred in the three time periods; therefore, a more detailed investigation is needed to see why these words were among the most frequent in all periods. This is also to check whether there are any constant/frequent discourses with Libya and Qaddafi across the three time periods or not. Going through the common words, it can be observed that Libya and Qaddafi were two of the query terms I used to compile the corpus, which made them to be frequent in the whole corpus. Some of the common words refer to the names of the countries where the newspapers are located and published (British in the Guardian, and United States in the $N Y T$ ), their style ( $M r$. in the NYT), and journalism related words (said in the two newspapers). The frequent use of the word British in the Guardian suggests the newspaper's interests in showing how some issues might affect how Britain deals with the national and international (critical) matters. The words united, government, states, American, and officials were predominantly used in the NYT showing how the US officials see and react to different events all over the world.

For the word/phrase to appear in the three investigated periods does not necessarily indicate that it was used similarly in these periods. The word government in the Guardian was usually used in the context of the United Kingdom as the frequent clusters British government, and Labour governments show. Also, it co-occurred with various nationalities such as Scotland, Libya, the U.S, Israel, China, Egypt, France, and Germany in period one; Libya, Syria, and Scotland in period two, and Libya, Syria, the U.S, Algeria, and Scotland in period three as shown in the cluster analysis in table 4.

Table 4. Cluster analysis for the word government in the Guardian

\begin{tabular}{lll}
\hline \multicolumn{1}{c}{ 2009/2010 } & \multicolumn{2}{c}{ The Guardian (Government) } \\
\hline Scottish government & Libyan government & \multicolumn{1}{c}{ British government } \\
British government & British government & Libyan government \\
Libyan government & interim government & Syrian government \\
UK government & UK government & UK government \\
US government & Syrian government & new government \\
Israeli government & transitional government & US government \\
American government & Qaddafi's government & coalition government \\
Chinese government & coalition government & transitional government \\
Egyptian government & US government & Algerian government \\
French government & rebel government & unity government \\
German government & Scottish government & Scottish government \\
\hline
\end{tabular}

The Scottish government, for example, was repeated in the three time periods mainly in the context of Megrahi, the prime suspect in the 1988 Lockerbie bombing to discuss the decision of his release, sending him back to Libya, and his death there. Some clusters such as the interim government, transitional government, coalition government, and rebel government began to appear on the surface in 2011 after the outbreak of the uprisings in the Arab region, and this suggests that a change in the status quo ocurred somewhere. In the third period, similar clusters to the ones observed in period 2 were found, in addition to some other clusters that suggest the establishment of new/unity governments. The Syrian government ranked 3rd as most of the main Arab protests have overthrown the presidents by that time except in Syria where civil war is still going on.

The word $\boldsymbol{M r}$ was mentioned frequently in the $N Y T$ as the newspaper uses it as a title term for male characters regardless their positions as table 5 shows. 
Table 5. Cluster analysis for the word $M r$. in the NYT

\begin{tabular}{clclcl}
\hline \multicolumn{5}{c}{ The NYT $(\boldsymbol{M r}$. $)$} \\
F. & $\mathbf{2 0 0 9 / 2 0 1 0}$ & F. & $\mathbf{2 0 1 1}$ & F. & 2012/2013 \\
\hline 324 & Mr. Megrahi & 1441 & Mr. Obama & 2495 & Mr. Obama \\
127 & Mr. Obama & 369 & Mr. Assad & 911 & Mr. Assad \\
75 & Mr. Khan & 296 & Mr. Gates & 823 & Mr. Romney \\
40 & Mr. Brown & 287 & Mr. Sarkozy & 328 & Mr. Kerry \\
34 & Mr. Burroughs & 259 & Mr. Mubarak & 255 & Mr. Putin \\
34 & Mr. Macaskill & 234 & Mr. Qaddafi & 232 & Mr. Stevens \\
33 & Mr. Netanyahu & 228 & Mr. Saleh & 221 & Mr. Mandela \\
29 & Mr. Bashir & 216 & Mr. Putin & 197 & Mr. Petraeus \\
27 & Mr. Assayas & 166 & Mr. Cameron & 172 & Mr. Hagel \\
27 & Mr. Qaddafi & 155 & Mr. Erdogan & 172 & Mr. Ryan \\
24 & Mr. Damache & 136 & Mr. Cain & 169 & Mr. Hollande \\
22 & Mr. Taylor & 112 & Mr. Panetta & 159 & Mr. Sarkozy \\
21 & Mr. Berlusconi & 95 & Mr. Ibrahim & 147 & Mr. Morsi \\
21 & Mr. Chavez & 95 & Mr. Medvedev & 135 & Mr. Cameron \\
\hline
\end{tabular}

Based on the corpus analysis, it was rare in the NYT to observe names of people without preceding them with titles such as $\mathrm{Mr}, \mathrm{Mrs}$, president, colonel, prime minister and others. Table 5 contains the names of some people who were considered prominent in the investigated period (2009-2013) in the Libyan-US context. Megrahi, the prime suspect in the Lockerbie bombing was the most frequent person in period 1. Some other names which are related to the same case were also frequently mentioned such as Brown, Britain's former PM, and MacAskill, Scotland's Justice Secretary. In 2011, the names of some Arab presidents whose countries were mainly involved in the protests were mentioned, such as Assad, Mubarak, Qaddafi, and Saleh. Qaddafi ranked 6th in period 2 though he was one of the query terms because he was referred to, in the majority of cases, as Colonel Qaddafi. In period 3, Obama and his republican rival in the US presidential election, Romeny, were mentioned frequently. The president Assad of Syria, and Mohammed Morsi, the first elected president in Egypt after the 2011 uprisings, were the most frequent Arabs in period 3.

In order to get a general idea about the representation of Qaddafi in the two newspapers, and check whether there are any constant discourses with him in the three periods, I carried out a cluster analysis for the common word Qaddafi in the two newspapers as table 6 shows. The cluster size is selected to be between 2 and 5 words, and the minimum frequency is set as 5 .

Table 6. Cluster analysis for Qaddafi in the two newspapers

\begin{tabular}{ccc}
\hline & Cluster Analysis for Qaddafi & Period 3 \\
\hline Period 1 & Period 2 & Qaddafi Regime \\
\hline Colonel Qaddafi & Qaddafi's Forces & Colonel Qaddafi \\
Leader Muammar Qaddafi & Qaddafi Regime & Saif Al Islam Qaddafi \\
Libyan Leader Qaddafi & Colonel Qaddafi & Pro Qaddafi \\
Qaddafi's son & Pro Qaddafi & Qaddafi Era \\
Qaddafi Stadium & Qaddafi Forces & \\
\hline Colonel Qaddafi & The NYT & Colonel Qaddafi \\
Qaddafi The Libyan Leader & Colonel Qaddafi & Qaddafi Government \\
Seif Al Islam El Qaddafi & Qaddafi Forces & Uprising Against Colonel Qaddafi \\
Qaddafi Said & Qaddafi Government & Qaddafi Loyalists \\
Qaddafi's Son & Qaddafi's Forces & Qaddafi Era \\
Qaddafi would & Pro Qaddafi & Fall of Col Qaddafi
\end{tabular}

The cluster analysis of Qaddafi in the two newspapers (table 6) shows that the discourse of war began to appear in period 2 (2011) as the words forces, pro- and anti- suggest. Such discourse is not observed in period 1 (2009/2010) where Qaddafi seems to be reported and represented as any other world leader. Unlike period 1, the word regime which has negative discourse prosody being suggestive of illegitimate governments began to appear in period 2, and so negative representation of Qaddafi is expected. In period 3 (2012/2013), both war and 
post-war discourses are observed as some words like era, and fall suggest. The clusters Qaddafi's era, Qaddafi loyalists, and Saif Qaddafi are mentioned in this period perhaps to discuss their fate in the new Libyan state, and highlight their role in the atrocities that the toppled regime committed.

The cluster analysis of Qaddafi in the two newspapers showed that the cluster of Qaddafi regime was not found in period 1 , and only began to appear in period 2 . To check with which countries the word regime was used in the investigated corpus, I carried out a cluster analysis with a minimum frequency of 5 for regime in the two newspapers (table 7). I only considered the clusters that contain names of countries or people.

Table 7. Cluster analysis for regime in the two newspapers

\begin{tabular}{|c|c|c|c|c|c|}
\hline \multicolumn{6}{|c|}{ Cluster Analysis for regime } \\
\hline \multicolumn{2}{|l|}{ Period 1} & \multicolumn{2}{|c|}{ Period 2} & \multicolumn{2}{|c|}{ Period 3} \\
\hline \multicolumn{6}{|c|}{ The Guardian } \\
\hline \multirow[t]{5}{*}{ The Libyan Regime } & 6 & Qaddafi Regime & 292 & Assad Regime & 104 \\
\hline & & Qaddafi's Regime & 101 & Syrian Regime & 71 \\
\hline & & Libyan Regime & 90 & Qaddafi Regime & 60 \\
\hline & & Assad Regime & 48 & Assad's Regime & 31 \\
\hline & & Syrian Regime & 45 & Qaddafi's Regime & 26 \\
\hline \multicolumn{6}{|c|}{ The NYT } \\
\hline & & Qaddafi Regime & 113 & Assad Regime & 101 \\
\hline & & Assad Regime & 35 & Syrian Regime & 58 \\
\hline & & Syrian Regime & 34 & Qaddafi Regime & 20 \\
\hline & & Libyan Regime & 25 & Assad's Regime & 15 \\
\hline & & Qaddafi's Regime & 24 & The Iranian Regime & 14 \\
\hline
\end{tabular}

Table 7 shows that no clusters appeared in the NYT's list in period 1, while the Libyan regime was mentioned only 6 times in the Guardian. However, some clusters related to Libya and Syria, and Qaddafi and Assad began to appear in period 2, and continued to appear in period 3. This suggests that different discourses are employed in periods 2 and 3 in contrast with period 1. The clusters in period 3 also suggest that the focus moved from Libya towards Syria due to the ongoing civil war there.

Based on the cluster analysis above for the words Qaddafi and regime, there seems to be a shift in the representation of Qaddafi after the outbreak of the Arab uprisings.

\subsection{The Differences in the Frequent Lexical Words in the Three Periods (Unique words)}

In order to uncover the different news foci in the Guardian and the NYT in the three time periods, I examined the most frequent unique words, i.e., the words that occurred in (a) particular period(s) other than others as shown in table 8 .

Table 8. Unique words in the three periods in the NYT and the Guardian

\begin{tabular}{|c|c|c|}
\hline Newspaper & Period & Unique words in the Guardian and the NYT \\
\hline The Guardian & 1 & $\begin{array}{l}\text { Megrahi, Libyan, release, Scottish, UK, Britain, international, minister, decision, pounds, } \\
\text { Lockerbie }\end{array}$ \\
\hline The NYT & $2009 / 2010$ & $\begin{array}{l}\text { American, nuclear, world, years, oil, Libyan, Megrahi, Obama, Israel, international, State, } \\
\text { countries, Iran }\end{array}$ \\
\hline $\begin{array}{c}\text { The Guardian } \\
\text { The NYT }\end{array}$ & $\begin{array}{c}2 \\
2011\end{array}$ & $\begin{array}{l}\text { Libyan, regime, forces, military, Tripoli, NATO, Arab, UK, rebels, Britain, yesterday } \\
\text { Qaddafi, colonel, Libyan, military, forces, rebels, Obama, world, oil, NATO, security, Arab, } \\
\text { Tripoli }\end{array}$ \\
\hline $\begin{array}{c}\text { The Guardian } \\
\text { The NYT }\end{array}$ & $\begin{array}{c}3 \\
2012 / 2013\end{array}$ & $\begin{array}{l}\text { Regime, Syria, military, security, Syrian, year, international, Obama, president, Arab, Assad } \\
\text { Attack, Obama, Syria, security, military, American, like, state, world, war, political, Syrian, } \\
\text { time, foreign }\end{array}$ \\
\hline
\end{tabular}

\subsubsection{Period 1 (2009-2010)}

In period one (2009/2010), almost all of the unique words in the Guardian were used in the context of the 1988 Lockerbie plane bombing as the words Megrahi, Libyan, release, Scottish, minister, decision, and Lockerbie show. This is mainly because the only person convicted in the bombing, the Libyan Abdelbaset Ali al-Megrahi was freed 
on compassionate grounds and returned to Libya in 2009. In the Guardian, the name Megrahi was the second most frequent lexical word in period one and came after the reporting verb said, which is the most frequent content word in the whole corpus. In the NYT, if we exclude the words that are related to the country where the newspaper is located such as American, Obama, and state, the name of Megrahi, and some general words such as world, years, international, and countries, the remaining four words summarize the focus of the NYT in this period namely, Israel, one of the most important allies of the United States in the Middle East, Iran that has strained relations with the U.S., oil and nuclear; two core issues in the US politics.

Although Libya and Qaddafi were involved in different events in this period such as Libya's dispute with Switzerland over the arrests of one of Qaddafi's sons, Qaddafi's election as a chairman of the African Union, his visit to Italy, buying weapons from Russia, and signing agreement with the European Union to slow illegal migration, in the Guardian, the majority of the unique words in this period were used in the co-text of the Lockerbie plane bombing, while the NYT focused on Libya's oil and nuclear program and its relation with other countries, mainly Israel and Iran. Accordingly, the focus of both newspapers was a reflection of the interests of the countries where they are published, and was influenced by some other factors related to newsworthiness criteria that emphasize conflict and proximity.

The Guardian, being a national British newspaper, tends to give some focus to British news stories in addition to its coverage of international events, and so in the Libyan context, Megrahi's release was a "critical" event to be covered since it is considered as one of the worst terrorist attacks in Britain's history. In terms of newsworthiness, Phillips (2015) argues that "a disaster at home will attract more detailed and longer coverage than a bigger one far away" (p. 19). In the same vein, Bednarek \& Caple (2012, p. 42) also note that "what is newsworthy usually concerns the country, region or city in which the news is published". In the Guardian, the event was categorized as "national" in the headlines of the articles that discuss the decision of Megrahi's release as concordance 1 shows.

\begin{tabular}{lll|}
\hline National: Megrahi release: A question of compassion? How did Libya try to secure & August 2009.txt \\
National: Megrahi release: Business links: Libya pours millions into City & August 2009.txt \\
National: Megrahi release: Lockerbie bomber decision leaves SNP facing censure & August 2009.txt \\
National: Megrahi release: Downing Street: Brown accused of cowardice and & August 2009.txt \\
National: Megrahi release: Trade: British firms hope release will boost business & August 2009.txt \\
National: Megrahi release: Whitehall reaction: Miliband rejects claims of & August 2009.txt \\
National: Megrahi release: Analysis: Confusion as old and new Libya collide Libya's & August 2009.txt \\
National: Megrahi release: Bomber's welcome sparks warning from UK and US: & August 2009.txt \\
National: Megrahi puts Lockerbie appeal papers on website The man convicted of & September 200 \\
National: Megrahi case: Brown finally admits support for Lockerbie bomber release September 200 \\
National: Megrahi case: Exclusive interview: Britain has nothing to hide, says & September 200 \\
National: The new Libya: Ideology: Country's jihadis reject violence as leader bids & September 200 \\
National: Reports of Megrahi's death in Tripoli denied Abdelbaset al-Megrahi, the & October 2009.t \\
National: Megrahi release: Profile: Kenny MacAskill: A singleminded reformer with & August 2009.txt \\
National: Megrahi case: Anglo-American relations: Rise of the new powers puts & September 200 \\
National: Megrahi case: Political briefing: Brown's costly lack of courage Whatever & September 200 \\
\hline
\end{tabular}

Concordance 1. Categorizing the news about Megrahi as "National" in the Guardian

In spite of describing the decision of releasing Megrahi as Scottish in the Guardian, Britain was involved and frequently mentioned in this co-text. Wilkinson (2011) argues that although the decision of the release was taken on compassionate grounds, it appears to be extraordinary due to the seriousness of the terrorist crime involved pointing out that the UK government was able to exercise a veto over the release because of the UK major foreign policy and its wider security implications. However, the whole matter seems to be linked with oil, and how some institutions and elites in the West change their principles to win oil contracts; "ultimately, Megrahi's release is such an affront to common sense that one can be forgiven for thinking that the Scots released him for the same reason many believe the Americans invaded Iraq: oil" (Hall, 2010, p. 268). In the Guardian, those who agree and disagree with the decision of the release were reported, providing balance in the story by introducing the opposing voices. For example, in the Guardian's coverage of the release, the newspaper tended to cover the event by focusing not only on the British point of view, but also highlighting the American, Scottish and even Libyan reaction on the decision of the release. However, the Libyan points of view were mentioned less than the other voices. Cushion (2012) argues that in the newsrooms of the UK, there is a built-in requirement to provide 
space for secondary voices. This means that there will be a space for oppositional reading although the elite source will be given more space and given the final words.

The unique words in the NYT also reflected the type of news covered and preferred by the newspaper in the Libyan co-text; for example Israel was one of the most frequent words in this period because it is seen as the US most reliable strategic partner in the Middle East, and at the time of conflicts, America sides always with Israel (El-Bendary, 2011) providing it with massive and unconditional financial, diplomatic, military and intelligence support. In addition, the Palestinian-Israeli conflict is considered to be newsworthy, and so attracts the media and the public. Some main themes were mentioned in this period in the NYT, namely oil and nuclear weapons. Huliaras (2006) referred to some factors that influence the U.S. policy toward other countries especially the oil-rich ones; mainly the war on terror, and oil interests. Regarding the other discussed theme in the NYT in this period, the newspaper reflected the vital role of nuclear weapons in the U.S. national security policy and how they sometimes determine its relations with other countries (Buchan, 2002). Accordingly, the focus of the NYT in this period was, to a great extent, in harmony with the interests of the Unites States and its foreign policy. In addition, the two discussed topics, i.e., oil and nuclear weapons are considered to be newsworthy especially when accompanied with some other factors which include socio-economic factors, physical and cultural proximity to home (the U.S. in this case), and others.

\subsubsection{Period 2 (2011)}

Period 2 is a key phase in this study since the Libyan uprisings that led to the Libyan civil war happened in it. In this section, I examine whether the focus of the two newspapers are affected by the pressure of the international community especially after Qaddafi's "violence" in facing the uprisings and his decision to fight his own people. As shown in table 8, and unlike period 1, there was more coverage of the situation in Libya, perhaps because news organizations generally favor novel, large-scale developments that represent a change from the status quo. Moroever, in Western democracies "news stories containing a conflict, however small, are far more likely to make it onto the pages than those that are simply reports of the status quo" (Phillips, 2015, p. 18).

Some of the unique words mentioned in table 8 occurred in the two newspapers, namely NATO, forces, military, and rebels. Putting the foreign news (civil war in Libya in this case) into a domestic context to explain to readers their importance and consequences, both newspapers focused on the role of the international coalition in saving the lives of the "innocent" civilians in some of the Arab Spring countries. To further examine this role, I analysed a unique word that occurred in the Guardian's and the NYT's lists in this period, namely NATO. Before carrying out a corpus analysis for this word, I investigated the main purposes/motives of the NATO intervention in Libya. The legitimacy of its intervention, according to R2P doctrine (Responsibility to Protect, 2005), is humanitarian, and derived from the international community's right intention to stop or prevent human suffering. Evans (2008, p. 143) points out that "mixed motives, in international relations as everywhere else, are a fact of life". Pattison (2011) argues that the humanitarian motives might be switched to regime change as the intervention goes on. In the Libyan case, the main motive is said to be Libya's major role in global oil markets. For example, Castro (2011) mentions that the "Cuban President Fidel Castro had pointed at the "cynicism" of the West in using the cover of a humanitarian intervention to actually wage a war to gain control of Libyan resources, particularly oil" (p. 309).

To uncover how NATO was referred to in both newspapers, I carried out a collocation analysis, and categorised its statistically strongest 50 collocates (with highest dice score; an effect size statistic which is a measure of strength of association between two words) into three thematic groups as shown in table 9 .

Table 9. Thematic categories of the collocates of NATO in the Guardian and the NYT

\begin{tabular}{lll}
\hline Thematic Category & \multicolumn{1}{c}{$\begin{array}{c}\text { Collocates of } \text { NATO } \text { in the two newspapers } \\
\text { The Guardian }\end{array}$} \\
\hline Military actions & $\begin{array}{l}\text { strikes, campaign, bombing, operations, } \\
\text { operation, commanders, planes, warplanes, air, } \\
\text { jets, strategy, targets, strike, hit, airstrikes, action, } \\
\text { aircraft, sorties, struck, no-fly, attacks, } \\
\text { intervention }\end{array}$ & $\begin{array}{l}\text { The NYT } \\
\text { targets, airstrike, general, operations, planes, strikes, } \\
\text { aircraft, bombed, defense, backed, bombing, airstrikes, } \\
\text { warplanes, strike, struck, attacks, attack, troops, } \\
\text { intervention, mission }\end{array}$ \\
\hline $\begin{array}{l}\text { Countries and Officials } \\
\text { and their role }\end{array}$ & $\begin{array}{l}\text { Fogh, Anders, Rasmussen, Brussels, France, } \\
\text { official, countries, alliance, allies, secretary, Italy }\end{array}$ & $\begin{array}{l}\text { Fogh, Anders, Rasmussen, Brussels, allies, alliance, } \\
\text { headquarters, Europe, secretary, partners, diplomat, } \\
\text { Afghanistan, Italy, Britain, European, Naples }\end{array}$ \\
\hline $\begin{array}{l}\text { Consequences and } \\
\text { Results }\end{array}$ & role, support, protect, cover & civilians, destroyed, conflict, protect, support \\
\hline
\end{tabular}


As can be observed in table 9, the thematic categories of the NATO's collocates in both the NYT and the Guardian are identical; however, in some cases the collocates themselves are different, and the concentration on one particular category rather than another is also observed. For example, when going through the concordance lines, I found that the concentration in the NYT was on Obama and the United States rather than Britain and France as in the Guardian.

Military Actions. In the Guardian, I investigated the statistically strongest collocate in this group strikes, and found that the British enthusiasm and justifications for NATO's intervention in Libya were highlighted. Britain, for example, emphasized that the bombing strikes would not end in Libya until Qaddafi stops "slaughtering" his own people. Britain and France are frequently referred to as the countries that are leading the military actions against Qaddafi. In the Guardian, NATO's strikes are said in almost all cases to target Qaddafi's troops and military sites. NATO was also said to help the rebels to advance in some regions by backing them by powerful air strikes.

In the NYT, I also investigated the statistically strongest collocate targets, and found that the focus was on the nature of the NATO's targets being against the systematic attacks on the Libyan civilians by the regime of Qaddafi. NATO's role in supporting the rebels was also highlighted in several incidents; for example, its airstrikes cleared the lands, and gave the rebels the opportunities to advance. Sometimes, NATO's "unintentional" killing of civilians is justified by saying that Qaddafi's forces mixed with the civilians to protect themselves from the air attacks. Accordingly, in both newspapers, the military action of the NATO is said to be against the Qaddafi forces that kill the Libyan civilians (negative out-group description), and its aim is to protect the Libyan civilians (positive in-group description).

Officials and Countries. Anders Fogh Rasmussen was the most quoted person in the co-text of NATO because he was, at that time, the Secretary General of NATO. Therefore, most of the official news about the raids on Libya was revealed by him. The collocate Brussels is mentioned since it is the place where NATO's headquarters are. In the Guardian, two countries were saliently mentioned in the co-text of NATO, namely Italy and France. In the NYT's coverage, more focus was given to Obama and Washington, and so the White House rather than Brussels was portrayed as the place where decisions are taken. In the same vein, the NYT put more focus on the US rather than the European role in supporting the military operations in Libya. It is also reported that the U.S., at the beginning, decided to lead from behind to force the European countries to "take responsibility for protecting their own back yard". This, according to some voices reported in the newspaper, implies that the U.S. is no longer prepared to "offer unconditional defence guarantees" to the European countries if they are not prepared to do more themselves. As a consequence, the European countries took the leading role in Libya. However, after two months, they ran critically low on munitions, and the U.S. intervened and sold the alliance ordnance saving NATO from embarrassment. This implies that the European countries lack a number of essential military capabilities and should spend more wisely on defence. Based on this, it appears that the NYT, by showing the "weakness" of the leading European countries, tended to portray the U.S. as the strongest and most dominant country in the world, and as the one that steps in not only to defend the rights of the third world countries, but also to save the reputation of some other very strong countries. Accordingly, the story of the NATO intervention in Libya becomes a case of coverage that focuses on the US perspective and military interests. Covering the story this way also contributes to sustaining the American people's confidence in their armed forces and political system (Fialka, 1992).

Consequences and Results. When investigating how the verb protect was used as a collocate with NATO in this category, I found that it is mainly used in the Guardian in two contexts. First, to emphasize the apparent reason behind the West intervention in Libya that is "to protect the Libyan civilians" (frequent), and second reporting some Libyan officials who claimed that the excuse of NATO's intervention to protect the civilians is fake as scores of Libyan civilians died since the airstrikes began, and the bombing delivered far more killing than before (not frequent). By doing so, the Guardian seems to achieve some core principles of journalism represented here by reporting the different voices regarding the intervention in Libya; the British officials and the international coalition (first context), and some of the Libyan officials (second context). However, although the newspaper provided some space for secondary voices (Qaddafi's loyalists in this case), more space was given to the other party that includes anti-Qaddafi groups and some Western officials. This means that there was a space for oppositional reading (pro-Qaddafi sources), but still the elite sources (pro-international coalition sources) were given more space and had the final words on the topic.

In the NYT, investigating how the collocate support was used; I first thought that it is used in the context of supporting civilians and rebels. However, it was mainly used in the NYT to categorize the countries based on whether they supported NATO's intervention in Libya or not, and the US support for the military operations 
there being praised by the international community. This suggests that the US relationship with other states is not so much a humanitarian one, and that the US news media, as found by Kim (2014), tend to classify the world countries into specific categories based on their stance towards the United States. The collocate civilians was used in the co-text of NATO in two polemic contexts (concordance 2). First, NATO's apparent role in Libya to protect the Libyan civilians (lines 5, 7, 8, 9, 11, 12,14, and 24), and NATO's airstrikes killing civilians (lines 1, 2, $3,4,6,10,16,17,18,19,20,21,22,23,25$, and 26) although the speakers in the second category are, in most cases, Libyan officials who are loyal to Qaddafi. This suggests that in the NYT's coverage of the NATO's intervention in Libya, some people who disagree with the NATO narrative of the story were reported, providing some balance in the story by introducing the opposing voices. This is according to Phillips (2015) an important way of broadening the number of voices in a story. Moreover, this contributes to having a multiplicity of points of view. At the end, when all views have been taken into account, rational people can make better judgements (Phillips, 2015).



Concordance 2. The collocate civilian in the co-text of NATO in the NYT

Going through the concordance lines in the NYT, I found that the intervention in Libya is sometimes described as war (concordance 3). For example, some clusters/clauses such as "NATO in a third war in a Muslim nation" (line 2), "NATO coalition's war" (line 3), "NATO war" (line 4), "NATO-run multilateral war" (line 5), "NATO-led war" (lines 6 and 7), "NATO-led air war" (lines 8 and 9), and "NATO's air war in Libya" (lines 10 and 11) were found. This use apparently contradicts the UN Security Council resolutions 1970 and 1973 which were used to legitimatize NATO to conduct the so called "humanitarian intervention to Libya" to uphold human rights by saving lives. I think that the word war was used in the NYT because the European countries and NATO rather than the United States played the leading role in the intervention, and so it seems that other countries' wars can be described as that more easily. In addition, given that the United States' own wars are more likely labelled as "campaigns", "interventions" or other terms (the exception being the war on terror), this word might have also been used to reflect the opposing opinions of the NATO intervention in Libya. Moreover, Libya, the place where the conflict occurred, is a strategic area that is full of natural resources and so many powerful countries were motivated to intervene there. The situation in Libya and the international intervention there is 
similar to what happened in Iraq in 2003, where the Western power intervened allegedly to protect the region from Saddam Hussein's policies and his nuclear power. However, the ultimate goal was to take over the country's oil reserves (Klare, 2004; Lieberfeld, 2005 ). Therefore, it appears that the international intervention is seen in the majority of cases as a war on resources rather than humanitarian intervention to protect "innocent" civilians.

\begin{tabular}{|c|c|}
\hline N & Concordance \\
\hline & that has led both countries and NATO into waging war against the forces of the Libyan leader, Col. \\
\hline & involved, either directly or through NATO, in a third war in a Muslim nation. "We're not in a good place," \\
\hline & invested in the European rescue; the NATO coalition's war in Libya; and the denouement of the Arab Spring \\
\hline & on Libya had been twisted to encompass a NATO war against the Libyan government and saying they \\
\hline & costs." Libya represents the first NATO-run multilateral war where the United States has pulled back from \\
\hline & Africa and the Middle East, even as the NATO-led war in Libya drags expensively and bloodily toward \\
\hline & That would be a disaster. Just look at the NATO-led war in Libya in which only six out of the 28 NATO \\
\hline & unisia and Egypt, prompted a NATO-led air war against Libya and led to harsh crackdowns in \\
\hline & continued American participation in the NATO-led air war in Libya at its current level, even as he \\
\hline & activities in Libya, arguing that the NATO air war -- while officially limited to protecting civilians -- \\
\hline & \\
\hline & behind," if "leading" is even th \\
\hline
\end{tabular}

Concordance 3 . The collocate war in the co-text of NATO in the NYT

The analysis of the word NATO suggests that the coverage of both newspapers of the international intervention in Libya focuses on the US and British perspectives and interests bearing in mind that mass media plays a vital role in shaping the public's perception of the military and its missions. Such role is crucial; for example if media covered a particular military operation (the intervention in Libya in this case) positively; the public will probably react positively to it, and be convinced that the military has executed its mission in manners accepted by society (English, 2005).

Going through most of the unique words in this period, it appears that the two newspapers focused on the role of the international community in protecting the Libyan people, supporting the rebels, and reducing Qaddafi regime's systematic attacks on civilians. The Guardian focused on the European countries' efforts in helping the Libyan people, while the NYT highlighted the role of the U.S. in ending the conflict. This suggests that the two newspapers, to a great extent, reflected the policies of the countries where they are located and mainly published producing narratives of "good" wars, on the side of justice and emancipation. Lindström \& Zetterlund (2012) argue that legitimising international support in Libya was linked with humanitarian threat that the Libyan citizens face, and the conflict was portrayed by media like a play in which good fights evil where Qaddafi represented the villain, some others (mainly France and the UK) played the role of good guys, while the U.S. chose a more discreet but very crucial role as a prompter.

Unlike period 1, the similarities in the unique words in this period were more than the differences not only in the unique words themselves but also on how these words were represented. Two points can be drawn from this; first, the Arab Spring represented a turning point in the focus of the two newspapers, and second, the Arab Spring not only attracted the attention of the Western countries and media, but also led to some convergence of their political points of view on how to deal with conflicts in the Middle East. For decades, the United States and some European countries had the tendency of tolerating the violations of human rights in some Arab countries (Eran, 2011). Such tolerance might be interpreted by the fact that the leaders of most Arab countries are allies of the West. However, this might not be accurate as such lenient reaction was applicable with Iran, which has strained relationship with the West after the Iranian authorities' violence against the Iranian demonstrators following the 2009 elections. Accordingly, it appears that there are some other factors that influence the West's reactions to some events, and these could be related to the countries' network of relations and interests, leading them to militarily intervene in some cases and only verbally criticize and condemn in others. Such variety of reaction "conveys a message of double and triple standards, of interests overcoming morality, and of extreme action being taken against tyrannical regimes only when there is no economic and/or political cost for such action" (Eran, 2011, p. 16). Regarding the British reaction to the Arab Spring, Leech, \& Gaskarth (2015) argue 
that the British government's responses to the era of uprisings in the Arab world are criticised for being inconsistent and selective and seen as evidence of unethical foreign policy-making. Similarly, Kitchen (2012) refers to the United States' cautious and contradictory approach to the Arab Spring. Both countries condemned the government violence in Libya, and rarely commented on the brutality in Bahrain, Egypt, Tunisia, and Yemen. Therefore, although newsworthiness is an important factor in determining which news should be covered more, the country where that media operates may have its own preferences about the depth and emphasis of news coverage, especially when the dicussed event is sensitive as in the case of conflicts and wars (Baum \& Zhukov, 2015).

\subsubsection{Period 3 (2012-2013)}

I now turn to investigate how the post-uprisings period (2012/2013) is represented in the two investigated newspapers. Based on the unique words of this period (table 8), it seems that there is a shift from the Libyan uprisings towards the Syrian case as some words such as Syria, Syrian, and Assad show. This is due to the civil war that erupted there after the president Assad of Syria rejected to step down and his governmental forces committed "cruel" deeds against the Syrian people.

In this section, the unique words regime in the Guardian, and attack in the NYT will be investigated because I found them the most relevant to the Libyan case and the study's overall objectives. I carried out a cluster analysis to examine how the unique word regime was used in the Guardian (table 10).

Table 10. The most frequent clusters with regime in the Guardian

\begin{tabular}{ll}
\hline \multicolumn{2}{l}{ Cluster analysis for the word “regime" } \\
\hline The Guardian & Freq. \\
\hline ASSAD REGIME & 104 \\
'S REGIME & 72 \\
SYRIAN REGIME & 71 \\
QADDAFI REGIME & 60 \\
REGIME CHANGE & 54 \\
OLD REGIME & 27 \\
FORMER REGIME & 26 \\
QADDAFI'S REGIME & 26 \\
REGIME FORCES & 25 \\
AL-ASSAD'S REGIME & 16 \\
\hline
\end{tabular}

The cluster regime change was used about 85 percent of the time with the Syrian regime to highlight the demands of the international community for Assad's immediate departure. Investigating how Assad was referred to in the co-text of regime, I found that he was mentioned in a variety of contexts. These include: the Russian support for him, his regime's chemical power and its effect on the region, the sectarian division in Syria, and finally the cruelty and violence of his regime against the Syrian people. The representation of the Assad's regime varied but negativity was dominant in the Guardian, followed by neutrality, with few or no positive descriptions. His regime is described as dictatorial, criminal, brutal, pernicious, and cancerous. Some clusters in table 10 such as regime change, old regime, and former regime were mainly used to question whether the loyal people for the old and former regimes will play any roles in the post-revolution period or not. That was also to highlight the risk of overthrowing the heads of the regimes and keeping their residues in critical positions, so some phrases such as former regime's security apparatus, loyalists, elements, and officials were frequent. It appears that the Guardian, by referring to such issues in the post-uprisings era, wants to highlight that the role of the international community that helped in the toppling of some long-standing regimes is almost done, and it is now the role of the new authorities to restore stability. Also, negatively representing the regime of Qaddafi, and highlighting the atrocities it committed throughout the past 42 years imply that the intervention in Libya that was led by Britain and overthrew Qaddafi was the right decision to be taken to save the innocent Libyan civilians. Accordingly, the focus was not only on the conflict arena at the time of the crisis, but also on the causes of how the conflict arose in the first place (oppression, suppression, and lacks of human rights). Hällgren (2012) argues that if news reporting dedicated some room for understanding the cultural context of the place where the conflict happens, some acts of the parties taking part in the war may become more understandable.

In the NYT, to investigate how the unique word attack was used, I carried out a collocation analysis, and examined the statistically strongest collocates (table 11). 
Table 11. Top collocates with the word attack in the NYT

\begin{tabular}{lccc}
\hline \multicolumn{4}{c}{ Collocates of “attack” in the NYT } \\
\hline Collocate & With & Relation & Total \\
\hline DEADLY & attack & 0.012 & 54 \\
TERRORIST & attack & 0.011 & 105 \\
KILLED & attack & 0.011 & 114 \\
SEPT & attack & 0.011 & 65 \\
CARRIED & attack & 0.010 & 36 \\
SEPTEMBER & attack & 0.010 & 41 \\
DIPLOMATIC & attack & 0.010 & 100 \\
MISSION & attack & 0.009 & 115 \\
RESPONSIBILITY & attack & 0.009 & 21 \\
COMPOUND & attack & 0.009 & 44 \\
INITIAL & attack & 0.008 & 23 \\
CONSULATE & attack & 0.008 & 45 \\
RESPONSE & attack & 0.008 & 31 \\
LED & attack & 0.008 & 20 \\
INVESTIGATION & attack & 0.008 & 17 \\
BENGHAZI & attack & 0.008 & 235 \\
\hline
\end{tabular}

Carrying out a concordance analysis for these collocates, I found that most of them are related to the Benghazi attack that took place on the evening of September 11th, 2012, and targeted the American diplomatic compound. The attack resulted in killing the US ambassador and three other officials. Although there were different bombings and crimes in the post-Qaddafi era, this particular event was privileged in the NYT and a detailed and long coverage was dedicated to it, probably because it is salient to the newspaper's main targeted audience (US People). Moroever, the power of the United States and its symbolic role in the region played an important role in giving the attack such particular resonance, and so much coverage was dedicated to this story not because of its relevance to the security situation in Libya but perhaps because of its reflections and consequences on the other "Western" countries that have embassies in the Arab region in general and the Arab Spring countries in particular. The collocates Benghazi and consulate refer to the place and the targeted institution of that attack. To see how the event was described, I first examined how the verb carried was used, and found that there was no clear reference to the person/group that carried out the attack. However, some different opinions regarding the doers and their relationship to Qaida were covered. The collocate terrorist was used 105 times to describe not only the 2012 Benghazi attack, but also different events or attacks (lines 2, 5, 28, 34 in concordance 4); however the majority of the cases referred to the "brutal" (line 32), "deliberate" (line 10), "organized" (line 8), "lethal" (lines 3 and 27), and "horrible" (line 12) terrorist attack on the US consulate in Benghazi. The attack was also used by the Republicans in the US presidential election to accuse Obama's administration of playing down a terrorist link to the attack to save Obama's re-election chances (lines 23 and 24). The newspaper sometimes concentrated on the time of the attack because it happened at the same time of the New York attack on September $11^{\text {th }}, 2001$. Therefore, some expressions such as "September attack", and "the Sept. 11 attack" were frequent (lines 19, 26, and 33). Other times, the concentration was on the place and the targeted institution as in the clusters: "the Benghazi attack", "embassy attack", and "consulate attack" (lines 7, 11, 15, 18, 24, and 25). 


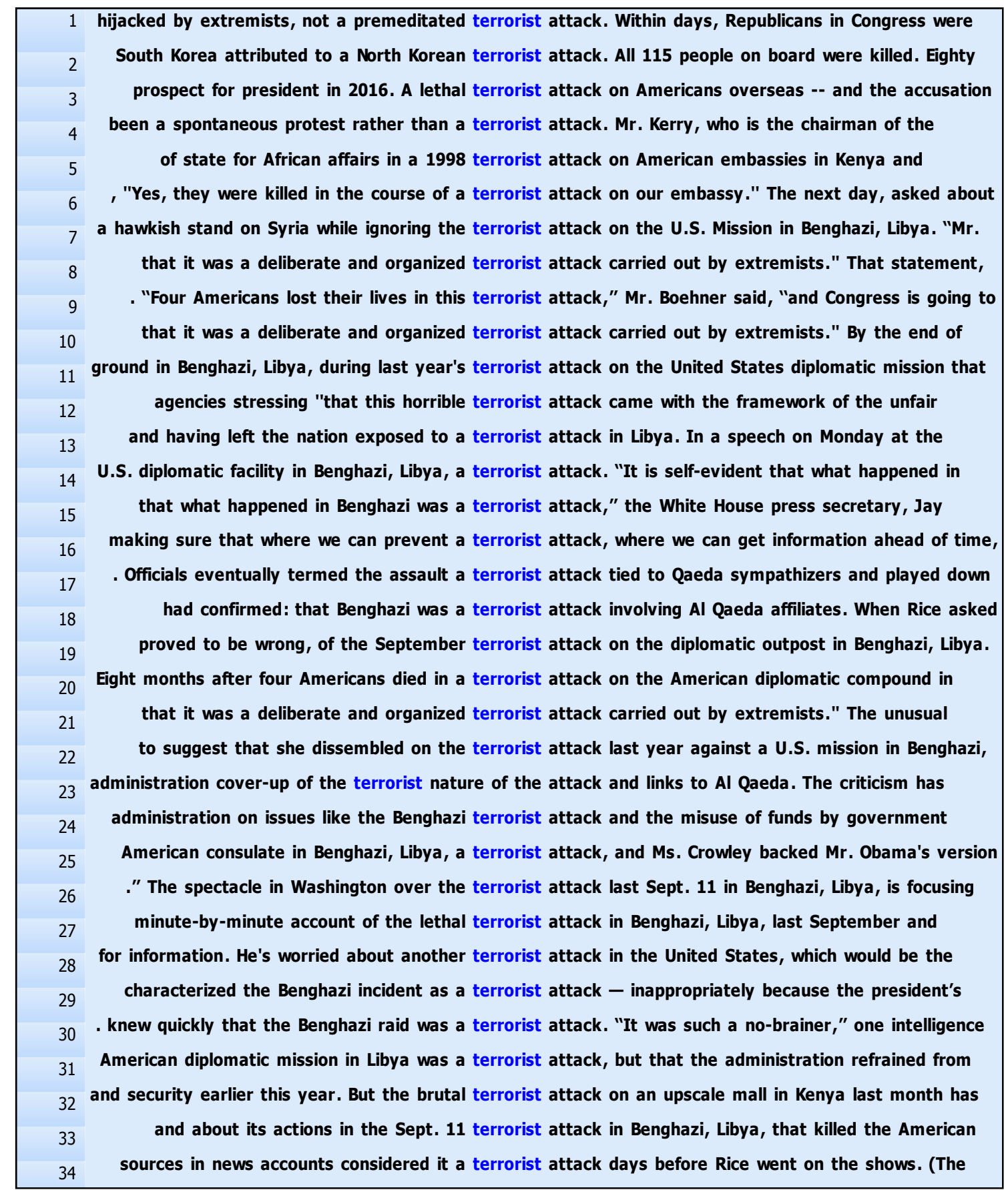

Concordance 4 . The word terrorist in the co-text of attack in the NYT

The high frequency of the word attack and some other words in the NYT suggests that the newspaper gives more focus mainly to covering news stories that are related to the US relations with some Arab countries in the Middle East and North Africa rather than focusing on how new civilized societies may be established. To read this from a different angle, the focus on Benghazi is also very significant in terms of the US domestic politics. For example, some US domestic words such as administration, officials, Republican*, and department were collocates with Benghazi and the attack that happened there, and this would suggest how much this was domestic not international news for the NYT. In addition to the saliency and relevance of this event to the American audience, the attack was also densely covered in the NYT when compared to its counterpart (the Guardian) perhaps because the newspaper wanted to highlight that the "US citizens are major victims of international terrorism" (Neumayer \& Plümper, 2011, p. 3) not only in their own country as happened on September 11th, 2001, but also abroad. This attack happened at a time of chaos and regime change. Kydd \& Walter (2006) note that terror 
groups seek to gain power and political influence in the countries where they are based and abroad. Moreover, the groups responsible for terror attacks usually aim to gain some support from the population (Enders \& Sandler, 2006). In the same vein, it is argued that "terrorism serves as an instrument used by radical political groups which aim at gaining influence on important policies and political control in their home country (or wider region)" (Neumayer \& Plümper, 2011, p. 5). This interpretation might fit the situation in post-Qaddafi Libya as there was a power vacuum that led at the end to violence in almost everywhere in the country. Moreover, Green (2011) argues that the era of the Arab uprisings is seen by terrorist groups as an anti-Western phenomenon. This might explain why some "terrorist" acts against the diplomats and embassies of some Western countries occurred in the aftermath of the Arab Spring.

The unique words analysis in the NYT and the Guardian in this period showed that the two newspapers gave much space to the Syrian case, on the one hand, and the consequences of the Arab revolutions on the other one. The two newspapers referred to the case of chaos that spread across not only the main Arab spring countries, but also the region in the post-uprisings era. Sometimes, such consequences are said to be inevitable linking the Arab Spring with other revolutions throughout history. For example, in Libya and although the country has been suffering from different problems since the 2011 overthrow of the Qaddafi regime, the Guardian focused on the democratic aspect that the uprisings provided people with; holding the first election in the country since about four decades. This might be to legitimise the international coalition in which the UK took the leading position. Similarly, on some occasions, the Guardian referred to the absence of a functioning state in the post-Qaddafi era and how the state needs to be built from scratch, not because the international coalition destructed the infra-structure, but because of the fragility of the Libyan state at the time of Qaddafi that left no institutional infrastructure behind. In the NYT, the focus in the post-Qaddafi Libya was on the security situation and how Libya became a safe haven for Qaida-linked groups. This is likely because the American institutions in Libya were targets for "terrorist" attacks; an example of this is the Benghazi attack on the American consulate that led to the killing of the US ambassador, and was described in the NYT as "brutal", "deliberate", "organized", "lethal" and "horrible". Therefore, and unlike the Guardian, the theme of terrorism continued to be covered heavily in the NYT highlighting how it is a vital matter in the American foreign policy especially in the Middle East.

\section{Conclusion}

In this study, a corpus of about 7 million words is used to examine how frequencies can direct the analysts toward news foci/themes. In this paper, I asked two questions, to which I now return:

- $\quad$ Are there any constant/frequent discourses with Qaddafi in The Guardian and The NYT from 2009 to 2013 ?

- What are the most frequent topics/themes discussed in news articles relating to Libya and Qaddafi in the pre-, during, and post- uprisings periods?

I examined the most frequent 25 lexical words in the Guardian and the NYT. The common words analysis, which refers to the words that occurred across the three investigated time periods when investigating the most frequent 25 words, suggests the absence of prominent/common discourses with Qaddafi in the three periods. The findings also showed that the discourse of war began to appear in period 2 (2011). Such discourse was not observed in period $1(2009 / 2010)$ where Libya and Qaddafi seem to be reported and represented as any other country and leader. In period $3(2012 / 2013)$, both war and post-war discourses were observed. This supports the idea that there was a change in the way Qaddafi was represented before 2011 (pre-revolution period), and after it (post revolution period). Therefore, it appears that the different types of media during the Arab uprisings brought "critical news and opinion to a broad public, gave voice to the voiceless, built ties between activists and ordinary citizens, and linked local protests into a powerful master narrative of regional uprising” (Lynch, 2015, p. 90).

After examining the words that occurred in the three periods, I investigated the most frequent unique words in each period separately by looking at the words that only occur in (a) particular period(s) rather than others. The aim behind this was to uncover the different news foci about Libya and Qaddafi in the three periods. In period 1, the Guardian mainly covered the release of Megrahi, while the NYT focused more on nuclear program issues, oil, and Libya's relation with other countries. Therefore, the two newspapers discussed Libya's involvement in some events on the international arena. This period was taken as a baseline and a starting point to measure and assess the newspapers' style and type of coverage in the other two periods. In period 2, the two newspapers mainly focused on the outbreak of the Arab uprisings, and how the security forces in most of the involved countries responded "severely" and "violently" to the demonstrations against the regimes. The situation in Libya was heavily and predominantly discussed, simply because the whole corpus was built using some query terms related to the Libyan civil war. Moreover, given the newsworthiness preferences in the market-oriented media, more coverage of the 2011 Libyan civil war and Qaddafi was expected in this period especially in the days of heavy 
fighting and when the the Qaddafi forces and loyalists commit atrocities against the Libyan civilians. Examining the unique words in this period, I found that the Guardian and the NYT highlighted the role of the international community in supporting the democratic waves in the Arab world, and NATO's role in protecting the Libyan people, supporting the rebels, and reducing Qaddafi regime's systematic attacks on civilians. In period 3, the two newspapers gave more space to the Syrian case, on the one hand, and the fate of the former regimes' residues, and the consequences of the Arab revolutions on the other one.

In common with Haider $(2016,2017)$, the analysis shows that there is a strong relationship between media and politics where media is a central arena for viewing the political events. The political coverage does not occur in a vacuum (Wolfsfeld, 2011). Also, politics has an impact on the news media. There are different factors that influence the media's tendency to "systematically" downplay or densely cover some events. These include newsworthiness factors, the policies of the country where the media organization operates, and news sources in relation to Western and non-Western countries. Regarding the political aspect, it is argued that the news agenda can be shaped by the state through direct ownership and media sources' control (Enikolopov, Petrova, \& Zhuravskaya, 2010), or through regulating the activity of privately owned media by placing licensing requirements and imposing laws that limit the use of particular forms of expression (Whitten-Woodring \& James, 2012). Although it is argued that media in democracies are in most cases independent from government influence as they mainly care about profit maximization, and have their own institutional biases, this study shows that media institutions operating in democratic societies are not immune from state influence. For example, at the time of wars and conflicts, there are some restrictions in reporting even in democratic states. These can be related to direct government censorship (Roeder, 1995), and rally-around-the-flag effects (Groeling \& Baum, 2008). Moreover, the state and media preferences may align.

\section{References}

Abu Hatab, W. (2013). Arab Spring Presidential Speeches and New Social Identities: A Critical Discourse Analysis Study. Paper presented at the The European Conference on Arts \& Humanities.

Al Nahed, S. (2015). Covering Libya: A Framing Analysis of Al Jazeera and BBC Coverage of the 2011 Libyan Uprising and NATO Intervention. Middle East Critique, 24(3), 251-267. https://doi.org/10.1080/19436149.2015.1050784

Al-Abed Al-Haq, F., \& Hussein, A. (2012). The Slogans of the Tunisian and Egyptian Revolutions: A Sociolinguistic Study. Issues in Political Discourse Analysis, 4(1), 39-58.

Al-Ali, N. (2012). Gendering the Arab spring. Middle East Journal of Culture and Communication, 5(1), $26-31$. https://doi.org/10.1163/187398612X624346

Al-Anani, K. (2012). Islamist Parties Post-Arab Spring. Mediterranean Politics, 17(3), 466-472. https://doi.org/10.1080/13629395.2012.725309

Baker, P. (2006). Using corpora in discourse analysis. London: Continuum.

Baker, P. (2010). Sociolinguistics and corpus linguistics. Edinburgh: Edinburgh University Press.

Bardici, M. (2012). A Discourse Analysis of the Media Representation of Social Media for Social Change-The Case of Egyptian Revolution and Political Change (Master Thesis). Malmö University, Sweden.

Baum, M. A., \& Zhukov, Y. M. (2015). Filtering revolution: Reporting bias in international newspaper coverage of the Libyan civil war. Journal of Peace Research, 52(3), 384-400. https://doi.org/10.1177/0022343314554791

Bednarek, M., \& Caple, H. (2012). News discourse. London: Continuum.

Blommaert, J. (2005). Discourse: A critical introduction. Cambridge Cambridge University Press. https://doi.org/10.1017/cbo9780511610295

Breheny, R. (2003). On the dynamic turn in the study of meaning and interpretation. In P. J (Ed.), Meaning: The dynamic turn (vol. 12, pp. 69-89). Dordrecht: Elsevier.

Buchan, G. (2002). Nuclear Weapons and US National Security Strategy for a New Century. RAND-PUBLICATIONS-MR-ALL SERIES, 225-273.

Burr, V. (1995). An introduction to social constructionism. New York; London: Routledge. https://doi.org/10.4324/9780203299968

Castro, J. E. (2011). Gaddafi and Latin America. Society, 48(4), 307-311. https://doi.org/10.1007/s12115-011-9442-7 
ComScore Data Mine. (2012). Most Read Online Newspapers in the World: Mail Online, New York Times and The Guardian.

Retrieved from http://www.comscore.com/Insights/Data-Mine/Most-Read-Online-Newspapers-in-the-World-Mail-OnlineNew-York-Times-and-The-Guardian

Cottle, S. (2011). Media and the Arab uprisings of 2011: Research notes. Journalism, 12(5), 647-659. https://doi.org/10.1177/1464884911410017

Cushion, S. (2012). The democratic value of news: Why public service media matter. Basingstoke: Palgrave Macmillan.

Dağtaş, B. (2013). Constructing the "Arab Spring": News discourses in Turkish newspapers. Global Media Journal, Canadian Edition, 6(2), 19-33.

Douglas, F. (2009). Scottish newspapers, language and identity. Oxford Oxford University Press. https://doi.org/10.3366/edinburgh/9780748624379.001.0001

El-Bendary, M. (2011). The" ugly American" in the Arab Mind: Why Do Arabs Resent America? Dulles: Potomac Books.

Enders, W., \& Sandler, T. (2006). Distribution of transnational terrorism among countries by income class and geography after 9/11. International Studies Quarterly, 50(2), 367-393. https://doi.org/10.1111/j.1468-2478.2006.00406.x

English, E. L. (2005). Towards a more productive military-media relationship: School of Advanced Military Studies United States Army Command and General Staff College, Fort Leavenworth, Kansas.

Enikolopov, R., Petrova, M., \& Zhuravskaya, E. (2010). Media and political persuasion: Evidence from Russia. American Economic Review, 101(7), 3252-3285.

Eran, O. (2011). The West Responds to the Arab Spring. Strategic Assessment, 14(2), 15-16.

Evans, G. (2008). The responsibility to protect: ending mass atrocity crimes once and for all. Washington: Brookings Institution Press.

Fialka, J. J. (1992). Hotel warriors: covering the Gulf War. Washington, DC: Woodrow Wilson Center Press.

Green, A. M. (2011). What Can We Predict About Libya and the Arab Spring from Statistical Studies? Statistics, Politics and Policy, 2(1). https://doi.org/10.2202/2151-7509.1029

Gries, S. T., \& Stefanowitsch, A. (2007). Corpora in cognitive linguistics: corpus-based approaches to syntax and lexis (Vol. 1). Berlin: Walter de Gruyter.

Groeling, T., \& Baum, M. A. (2008). Crossing the water's edge: Elite rhetoric, media coverage, and the rally-round-the-flag phenomenon. The Journal of Politics, 70(04), 1065-1085. https://doi.org/10.1017/S0022381608081061

Haider, A. (2016). Conflicts as causes to change news foci: Frequency analysis for Asharq Al-Awsat and Al-Khaleej newspapers before and after the Arab Spring. International Journal of English Language and Linguistics Research, 4(7), 18-45.

Haider, A. (2017). A Corpus-assisted Critical Discourse Analysis of the representation of Qaddafi in Media: Evidence from Asharq Al-Awsat and Al-Khaleej Newspapers. International Journal of Linguistics and Communication, 4(2).

Hall, A. L. (2010). Change We Can Believe In?: Commentaries on the Major Events of our Time. New York, Bloomington: iUniverse Inc.

Hällgren, L. (2012). Peace-and War Journalism: A critical discourse analysis of newspaper editorials on the topic of Iran's nuclear program. Umeå Universitet, Statsvetenskapliga Institutionen. Retrieved from http://www.diva-portal.org/smash/get/diva2:540134/fulltext01.pdf

Hanks, P. (2012). The corpus revolution in lexicography. International Journal of Lexicography, 25(4), 398-436. https://doi.org/10.1093/ijl/ecs026

Hardt-Mautner, G. (1995). Only Connect.' Critical discourse analysis and corpus linguistics'. UCREL (University Centre for Computer Corpus Research on Language). Technical Papers 6: Lancaster University. Retrieved from http://ucrel.lancs.ac.uk/papers/techpaper/vol6.pdf

Huliaras, A. (2006). Evangelists, oil companies, and terrorists: The Bush administration's policy towards Sudan. 
Orbis, 50(4), 709-724. https://doi.org/10.1016/j.orbis.2006.07.010

Hunston, S. (2002). Corpora in Applied Linguistics. Cambridge: Cambridge University Press. https://doi.org/10.1017/CBO9781139524773

Izadi, F., \& Saghaye-Biria, H. (2007). A Discourse Analysis of Elite American Newspaper Editorials: The Case of Iran's Nuclear Program. Journal of Communication Inquiry, 31(2), 140-165. https://doi.org/10.1177/0196859906298073

Jones, P. (2012). The Arab spring: Opportunities and implications. International Journal, 67(2), 447-463. https://doi.org/10.1177/002070201206700214

Kautsky, R., \& Widholm, A. (2008). Online methodology: Analysing news flows of online journalism. Westminster Papers in Communication and Culture, 5(2), 81-97.

Kim, K. H. (2014). Examining US news media discourses about North Korea: A corpus-based critical discourse analysis. DISCOURSE \& SOCIETY, 25(2), 221-244. https://doi.org/10.1177/0957926513516043

Kitchen, N. (2012). After the Arab Spring: power shift in the Middle East?: the contradictions of hegemony: the United States and the Arab Spring. In N. Kitchen (Ed.), IDEAS reports-special reports. London, UK: LSE IDEAS, London School of Economics and Political Science.

Klare, M. (2004). Blood and oil: The dangers and consequences of America's growing dependency on imported petroleum. New York: Metropolitan Books.

Kydd, A. H., \& Walter, B. F. (2006). The Strategies of Terrorism. International Security, 31(1), 49-80. https://doi.org/10.1162/isec.2006.31.1.49

Ledwell, T. (2012). The Story of Egypt: Journalistic impressions of a revolution and new media power. (MA Thesis), The University of London:, UK

Leech, P., \& Gaskarth, J. (2015). British Foreign Policy and the Arab Spring. Diplomacy \& Statecraft, 26(1), 139-160. https://doi.org/10.1080/09592296.2015.999631

Lieberfeld, D. (2005). Theories of Conflict and the Iraq War. International Journal of Peace Studies, 10(2), $1-21$.

Lindström, M., \& Zetterlund, K. (2012). Setting the Stage for the Military Intervention in Libya Decisions Made and Their Implications for the EU and NATO. Stockholm: Swedish Ministry of Defence.

Lynch, M. (2015). How the Media Trashed the Transitions. Journal of Democracy, 26(4), 90-99. https://doi.org/10.1353/jod.2015.0070

Maalej, Z. A. (2012). The "Jasmine Revolt" has made the "Arab Spring": A critical discourse analysis of the last three political speeches of the ousted president of Tunisia. DISCOURSE \& SOCIETY, 23(6), 679-700. https://doi.org/10.1177/0957926512452973

McEnery, T., \& Wilson, A. (2001). Corpus linguistics. Edinburgh: Edinburgh University Press.

Michel, H. (2013). "IrHal!": The Role of Language in the Arab Spring (MA Thesis). Georgetown University.

Neumayer, E., \& Plümper, T. (2011). Foreign terror on Americans. Journal of Peace Research, 48(1), 3-17. https://doi.org/10.1177/0022343310390147

Partington, A., Morley, J., \& Haarman, L. (2004). Corpora and Discourse. Bern: Peter Lang.

Pattison, J. (2011). The Ethics of Humanitarian Intervention in Libya. Ethics and International Affairs, 25(3), 271-277. https://doi.org/10.1017/S0892679411000256

Phillips, A. (2015). Journalism in context: practice and theory for the digital age. New York \& London: Routledge.

Responsibility to Protect. (2005). Responsibility to Protect: United Nations.

Roeder, G. H. (1995). The censored war: American visual experience during World War Two. New Haven, CT: Yale University Press.

Roland, D., Dick, F., \& Elman, J. L. (2007). Frequency of basic English grammatical structures: A corpus analysis. Journal of Memory and Language, 57(3), 348-379. https://doi.org/10.1016/j.jml.2007.03.002

Scott, M. (2012). WordSmith tools version 6. Stroud: Lexical Analysis Software.

Seeberg, P., \& Shteiwi, M. (2014). European Narratives on the "Arab Spring”-from Democracy to Security. 
DJUCO Joint Publications.

Seo, S. (2013). Hallidayean transitivity analysis: The Battle for Tripoli in the contrasting headlines of two $\begin{array}{lllll}\text { national newspapers. DISCOURSE } & \text { \& } & \text { SOCIETY, } & 24(6),\end{array}$ https://doi.org/10.1177/0957926513503267

Skulte-Ouaiss, J., \& Baroudi, S. E. (2015). Mohamed Hassanein Heikal on the United States: The Critical Discourse of a Leading Arab Intellectual. Middle Eastern Studies, 51(1), 93-114. https://doi.org/10.1080/00263206.2014.941820

Sparks, C. (2000). Introduction: the panic over tabloid news. In C. Sparks \& J. Tulloch (Eds.), Tabloid tales: Global debates over media standards (pp. 1-40).

Springborg, R. (2011). The Political Economy of the Arab Spring. Mediterranean Politics, 16(3), 427-433. https://doi.org/10.1080/13629395.2011.613678

Teti, A. (2012). The EU's First Response to the "Arab Spring": A Critical Discourse Analysis of the Partnership for Democracy and Shared Prosperity. Mediterranean Politics, 17(3), 266-284.

The Guardian. (2014). The Guardian overtakes New York Times in comScore traffic figures, The Guardian. Retrieved from http://www.theguardian.com/media/2014/oct/21/the-guardian-overtakes-new-york-times-in-comscore-traffi c-figures

Uribe, R., \& Gunter, B. (2004). Research note: The tabloidization of British tabloids. European Journal of Communication, 19(3), 387-402. https://doi.org/10.1177/0267323104045265

Van Dijk, T. A. (1997). Discourse as interaction in society. In T. A. Van Dijk (Ed.), Discourse as social interaction (Vol. 2, pp. 1-37). Newbury Park, CA: Sage.

Van Dijk, T. A. (2001). Discourse, ideology and context. Folia Linguistica, 35(1-2), 11-40. https://doi.org/10.1515/flin.2001.35.1-2.11

Whitten-Woodring, J., \& James, P. (2012). Fourth estate or mouthpiece? A formal model of media, protest, and $\begin{array}{lllll}\text { government } & \text { repression. } & \text { Political } & \text { Communication, } & \text { 29(2), }\end{array}$ https://doi.org/10.1080/10584609.2012.671232

Wilkinson, P. (2011). Terrorism versus democracy: The liberal state response. New York: Taylor \& Francis.

Wolfsfeld, G. (2011). Making sense of media and politics: Five principles in political communication. New York: Taylor \& Francis.

\section{Copyrights}

Copyright for this article is retained by the author(s), with first publication rights granted to the journal.

This is an open-access article distributed under the terms and conditions of the Creative Commons Attribution license (http://creativecommons.org/licenses/by/4.0/). 